\title{
Social Psychology and Health: Socio-Psychological or Psychosocial? Innovation of the Field in the Context of the Brazilian Responses to AIDS
}

\author{
Vera Silvia Facciolla Paiva ${ }^{1}$ \\ Departamento de Psicologia Social e do Trabalho da Universidade Estadual de São Paulo, \\ São Paulo, Brasil
}

\begin{abstract}
A critical review of the literature on the uses and meanings of the expression psychosocial in Brazilian journals opens this text. It will discuss how the Brazilian notion of "psychosocial mode" to organize mental health care, framed within the health reform movements in the $1980 \mathrm{~s}$, contributed to the formation of a field of studies and innovative practices, developed mostly in the context of the Brazilian response to AIDS. Its human rights perspective is unknown in its details as well as its constructionist approach to health psychology defined as psychosocial rather than socio-psychological, distinguished also by a psychosocial approach at the various levels and territories of prevention and care practices. The techniques and work processes derived from a unique Brazilian vulnerability and human rights approach (V\&HR) value the programmatic mediation of the inextricably linked social and individual vulnerability and, therefore, actions for mitigation of rights violations. Strongly inspired by hermeneutics and the social sciences constructivism, this approach to constructionist social psychology prioritize the comprehension of "inter-subjectivity in scene", understood as intrinsically related to socio-cultural scenarios - approached in programmatic encounters at health services through personal trajectory and everyday life scenes. The notion of person, taken as a subject of discourses and holder of rights, contrasts with the notion of a biological-behavioral individual of the health psychology tradition that remained active in other paradigms of health-disease processes. This article will provide references for a critical reflection on the historical and scholarly production in the field of AIDS included in this supplement.
\end{abstract}

Keywords: Social Psychology, human rights, vulnerability, constructionism, health promotion.

\section{Psicologia na Saúde: Sociopsicológica ou Psicossocial? Inovações do Campo no Contexto da Resposta Brasileira à Aids}

\section{Resumo}

Uma revisão crítica da literatura sobre os usos e o sentido do termo psicossocial em periódicos brasileiros inicia este texto. Discutirá, em seguida, como a concepção brasileira do "modo psicossocial" na atenção ao sofrimento mental, produzida no movimento pela reforma sanitária dos anos 1980, contri-

Address: Departamento de Psicologia Social e do Trabalho, Instituto de Psicologia, Universidade de São Paulo, Av. Prof. Mello Moares, 1721, Cidade Universitária, São Paulo, SP, Brasil 05508-900. E-mail: veroca@usp.br. We acknowledge the support of the Ford Foundation that invited us to systematize and then translate the production of over two decades that distinguishes the response to AIDS. The production of this supplement was possible as CNPq (National Counsel of Technological and Scientific Development) enhances my dedication to research and supported my coordination of the activities of NEPAIDS (Nucleus for the Study of AIDS Prevention at the University of São Paulo). This would not be possible without the companionship and joy at work of our colleagues in this network that bring about the NEPAIDS, the journal team and the reviewer's rigorous work. 
buiu para constituir um campo de estudos e práticas inovador, desenvolvido centralmente no contexto da resposta brasileira à Aids. Reconhecida internacionalmente, mas pouco conhecida na intimidade, a perspectiva baseada nos direitos humanos e de análise no quadro da vulnerabilidade (social, programática e individual) produziu uma vertente da psicologia social construcionista na saúde que se define como psicossocial e não sociopsicológica. As técnicas e processos de trabalho derivados desta abordagem da vulnerabilidade e dos direitos humanos $(\mathrm{V} \& \mathrm{DH})$ se distinguem pela valorização da mediação programática e, portanto, da ação pela proteção ou para mitigação da violação de direitos. Distinguem-se, ainda, pela abordagem necessariamente psicossocial das práticas nos diversos níveis e territórios de atenção e prevenção. Inspirada pela hermenêutica e pelo construcionismo social, essa vertente da psicologia social construcionista priorizará a compreensão da "intersubjetividade em cena" implicada em cenários socioculturais - nos encontros programáticos em serviços focalizará cenas cotidianas e da trajetória da pessoa. A noção de pessoa, tomada como sujeito de discursos e de direitos, contrasta com a noção de individuo biológico-comportamental da psicologia da saúde que permaneceu nos paradigmas para pensar o processo saúde-doença. Este artigo oferecerá, portanto, referências para uma reflexão crítica sobre o contexto histórico e acadêmico da produção no campo da Aids incluída neste suplemento.

Palavras-chave: Psicologia Social, direitos humanos, vulnerabilidade, construcionismo, promoção da saúde.

\section{Psicología en la Salud: Sociopsicológica o Psicosocial? La Innovación en el Contexto de la Respuesta Brasilera al SIDA}

\section{Resumen}

Este texto inicia con una revisión crítica de la literatura sobre los usos y el sentido del término psicosocial en periódicos brasileros. Discutirá cómo la concepción brasilera del "modo psicosocial" en la atención al sufrimiento mental, producida desde el movimiento por la reforma sanitaria, contribuyó para constituir un campo de estudios y prácticas innovador, desarrollado en el contexto de la respuesta brasilera al Sida. La perspectiva vulnerabilidad y derechos humanos (V\&DH), poco conocida en la intimidad, basada en los derechos humanos y en la análisis de la vulnerabilidad (social, programática e individual) produjo una vertiente de la psicología social construccionista en la salud que se define como psicosocial y no socio psicológica. Se distingue por abordajes psicosociales de las prácticas en diversos niveles y territorios de atención y prevención. Las técnicas y procesos de trabajo de este abordaje de la vulnerabilidad, destacan la mediación programática y, efectivamente, de la mitigación de la violación de derechos. Inspirada por la hermenéutica y por el construccionismo social, esta vertiente de la psicología social construccionista priorizará la comprensión de la "intersubjetividad en escena" implicada en escenarios socioculturales - en los encuentros programáticos en servicios focalizará escenas cotidianas y de la trayectoria de la persona. La noción de persona, concebida como sujeto de discursos y de derechos, contrasta con la noción de individuo biológico-comportamental de la psicología de la salud que permaneció en otros paradigmas sobre procesos salud-enfermedad. Este artículo ofrecerá referencias para una reflexión crítica sobre el contexto histórico y académico de la producción incluida en este suplemento.

Palabras clave: Psicología social, derechos humanos, vulnerabilidad, constructivismo, promoción de la salud.

A practical working knowledge is essential for the production of its renewal. If from practice we do not dedicate ourselves to create new theories, we waste the human work of reflection. The emergence of the AIDS epidemic in the ear- ly 1980s was undoubtedly a stimulus to innovation of practices, techniques and theories involved in the challenge of addressing the social and psychosocial dimensions of health-disease processes. 
Internationally acclaimed for having broadened the focus of the individualist approach, taking into account the social context and the adoption of policies to protect and promote human rights, the so-called "Brazilian response to AIDS", was stimulated innovation (Berkman, Garcia, Muñoz-Laboy, Paiva, \& Parker, 2005; Kerrigan et al., 2013; Nunn, da Fonseca, Bastos, \& Gruskin, 2009; Paiva, 2002). Some authors refer to its set of pioneering programs and practices, organized since the 1980 s, as being dependent on the active coordination between researchers, government and civil society who organized structural and institutional interventions before the existence of the SUS (Unified Health System). The rigorous production of accurate and scientific information along various dimensions of the epidemic counted on the participation of those directly affected by AIDS, something that distinguishes it from the response to several other endemic diseases in Brazil. An inspiration for other countries, its most notable success was the organization of a network of health services guided by the principles of the SUS and inter-sectorial planning, which offered free and universal access to HIV testing and comprehensive treatment for people diagnosed with HIV and prevention focused on condom use (Berkman et al., 2005; Greco \& Simon, 2007; Malta \& Beyrer, 2013; Paiva, 2002).

It is intuitive to recognize that these actions depend largely on psychosocial approaches, which were inspired by the traditions of the humanities and the social sciences applied to the health-disease processes and sexuality (Paiva, 2002, 2008, 2012a) and health practices based on human rights (Gruskin \& Tarantola, 2008b, 2012; Kalichman \& Diniz, 2009; Kerrigan et al., 2013; Nunn et al., 2009). As articulated in several articles in this supplement, psycho-educational and counseling practices guaranteed professional training from various sectors (health, education, justice, social welfare, and in private companies). Invested to understand and mitigate the process of stigmatization and discrimination, this capacity building value the interactions among professional-patient and provider-client, to support adherence to medication and promote condom use, with results comparable to those in the wealthiest countries of the northern hemisphere. Many of these practices resulted from a Brazilian conceptualization of the psychosocial dimensions in the process of health-illness, whose authors may not always be psychologists.

This theoretical and practical production is unknown internationally and deserves special attention by other thematic areas and disciplines. The more organized dissemination of this production has increased the quality of the response to other health problems (e.g., sexually transmitted diseases, abuse of drugs and alcohol, obesity, tuberculosis, and hepatitis) and responded to the challenge of the humanization of health practices.

This text provides some references for critical reflection on the historical context of this academic production and, in particular, about the meaning of the term psychosocial as used in the literature.

\section{The Use of the Term Psychosocial}

The "(low) quality of psychosocial care"2 and the need for (more) "attention to the psychosocial risks of clients"3 are frequent considerations made in texts on health care. Institutional documents to organize health programs and policies use this expression to indicate general principles of action to guarantee the principle of comprehensive care that expands clinical practice, which is often reduced to the administration of medication for illness. In much of the more academic literature, however, few scholars define precisely the meaning of the term psychosocial or of the psychosocial sphere that should be addressed. The literature devoted to describing the intimate details of these practices and of the processes that could benefit from this approach is even more uncommon.

It is not a simple task. To affirm a psychosocial domain means to integrate spheres historically treated as separate in professional training - the social separated from the individual and

Psychosocial care is the most commonly used term in English.

3 In several documents of Brazilian Ministry of Health (Ministério da Saúde, 2008). 
the society from the person. There is need to account for the hyphen in psycho-social ${ }^{4}$, a punctuation that indicates the relationship between compound words and was almost abolished in the grammatical reformation of the Portuguese language. Some authors writing in English in the field of psychology defend the hyphen because it means, at the same time, the irreducibility of the psychological dimension to the social (and vice versa), as well as the impossibility of one domain to exist without the other: they are complementary. Maintaining the hyphen they claim that there is "a difference that can never be overcome, yet one which continually invites engagement and exploration" (Hogget, 2008, p. 13).

How does the term psychosocial appear in the most accessible databases of the literature available in electronic format in Portuguese? Although we found it in numerous articles, books and theses ${ }^{5}$, psychosocial does not figure as a search term (descriptor) in the BVS-Psi ULAPSI system (the Health and Psychology Virtual Library, the Latin American reference center based in Brazil), dedicated to the professional development of psychologists and to the advancement of research in psychology. Moreover, it does not appear as search term in the health sciences DeCS used in SciELO. ${ }^{6}$ It is only found as an adjective associated with other keywords.

4 The debate about the hyphen was started by the Department of Social Psychology at the University of São Paulo by Belinda Mandelbaum, Luiz Galeão and Nelson da Silva Júnior, in an internal document in 2011, which was not published, to which I owe the inspiration for its discussion here.

5 In August 2013, we found the term psychosocial used in scielo.com in 841 articles, in BVS we found 390 along with 218 theses and 40 books that used the term.

6 SciELO - Scientific Electronic Library Online is a model for cooperative electronic publishing of scientific journals on the Internet. Especially conceived to meet the scientific communication needs of developing countries, particularly Latin America and the Caribbean countries, it provides an efficient way to assure universal visibility and accessibility to their scientific literature, contributing to overcome the phenomena known as 'lost science'. Literature on the 15-years of SciELO may be found athttp://www.scielo.org/ php/level.php?lang=en\&component $=42 \&$ item $=7$
When the source is the APA (American Psychological Association), we find the term psychosocial as a qualifier for a type of "rehabilitation" (cognitive, in drug abuse, physical) or associated with the phrase "psychosocial development", which can be used as synonymous with "social development" when referring to the work of Erik Erikson. To think of the character of the Brazilian production in this area, when the source of the term is the Brazilian $\mathrm{SBD}^{7}$, we found that it was frequently associated with the search terms "Center for Psychosocial Care" or "psychosocial intervention." In the health sciences terminology, we could not find its use, not even as an adjective.

In the literature available in SciELO that we reviewed $^{8}$, we found several meanings for the psychosocial domain or of what was qualified as psychosocial, and most of this work did not offer a precise definition of the term. The term is used to define a dimension that not only depends on the person (while studying the individual) or for qualifying phenomena understood as "social" and "psychological" at the same time, simply meaning that they could not be merely psychological or social. In addressing the process of health-illness, many available articles use it as it is referred to in the World Health Organization (WHO) definition of health, which refers to "the physical, mental, social and spiritual wellbeing."

For example, in describing the process of performing medical histories (anamnesis) ${ }^{9}$ as

7 Service of Library and Documentation, with the headquarters of the BSV-Psi ULAPSI located at the Institute of Psychology of the University of São Paulo.

8 This is a review of the subject based (Rother, 2007), made in scientific articles retrieved through SciELO using the search term "psychosocial" and the year of publication (2000-2012). As indicated by the objectives proposed in this article, it is a critical reflection on the use of psychosocial in the field of health. We chose the SciELO database because it focuses on journals that go through a more rigorous and systematic evaluation, and it is more indicative and representative of Brazilian journals with the highest ratings.

9 This history goes from initial symptoms to when the clinical observation and is performed based on the patient's memory. 
an example of how a psychosocial approach should be undertaken, we find recommendations to take into account the context of the patient's life. Another frequent example is suggested in practices of judicial assessment to evaluate the person home instead of an approach based on classical "psycho diagnosis"10, which is guided by a description of universal intra-psychic dynamics without context. The type of assessment that would include the situation in which people live is called a "psychosocial assessment".

Many texts speak of "psychosocial integration" referring to a body of work on support and rehabilitation for people adapting to a new condition of life. The most successful work on integration prevents isolation, suffering and social exclusion. The terms "psychosocial adjustment" and "psychosocial rehabilitation" are associated in this literature.

When the topic is children and adolescents, the notion of "psychosocial development" describes ways of adapting to what is expected in each stage of life, which are treated as essential and universal. Consequently, there is no mention of the context, especially related to gender, social class and cultural tradition, that children and youth inhabit. This understanding of the development process is more clearly defined when inspired by psychoanalysis. Most articles, however, do not refer to authors or to a clear concept of psychosocial development. A smaller group of articles refer to documents of the Brazilian Ministry of Health, such as those related to the organization of multidisciplinary teams in different territories and communities of mental health professionals, nurses, gynecologists and other type of clinicians - aiming for comprehensive health care (integral care is the expression in Portuguese, a principle of SUS). The notion of context is synonymous with "environment".

"Psychosocial development is understood as the human capacity of progressive acquiring the ability to interact with the environment" (Ministério da Saúde, 1993, p. 37).

10 The diagnostics of mental disorders that use psychological methods or tests.
As explored in this article, however, although the community and the environment are mentioned, most texts maintain the notion of "biopsychosocial maturation" and refer to the "risk of abnormality" produced by the context, the highest risk among the poor "in rural areas and in peripheries of urban centers" (Ministério da Saúde, 1993, p. 18).

On the other hand, there was an increase in the number of texts available in SciELO that consider the psychological concepts of "social support," "social networks" and "institutional relations", in contexts such as the family, the workplace, civil society organizations and the government. Reference to community is often done in relation to an identity that exists in segments of society grouped by their assumed or chosen psychosocial affinity - such as among homosexuals, religious groups, and people living with HIV.

In addition to this set of studies, in recent years there have been studies that include the psychosocial category to define power relations and citizenship, especially to gender relations, class relations, and, more rarely, to ethnic and racial relations. References to class, poverty, or to "gender issues" are included in the psychosocial domain, inspired by the tradition of cultural studies and the social constructionist perspective of gender. This body of work, in discussing the embodied difference between certain social groups (women and men, poor and rich) states that social inequality cannot be explained by "nature" or by inevitable social processes, such as historically established social structures. Moreover, inequalities are undesirable and not unchangeable. ${ }^{11}$ In this set of texts, however, few use class or gender as categories for analysis in their organization and narrative, as proposed by Brah (2006) and Scott (1988/1995).

11 As used by other Latin American constructionist authors', these articles quote Bourdieu, Gergen and Ibañez, or are inspired by George Mead, Berger and Luckmann, Goffman, and other writers marked by the symbolic interactionism as well as by pragmatism, cultural studies, feminist studies, and sexuality studies. Most read Foucault and, more recently, has been inspired by the philosophy of Gadamer, Habermas and Ricouer. 
This whole body of literature and its different approaches defines various phenomena as psychosocial: feelings, emotions, attitudes and practices, discourses drawn from the narratives of individuals or analyzed on the basis of documents, relational dynamics, discussing resistance and resilience, and scenes and contexts. The expression most frequently used by authors in the constructionist field is "psychosocial aspects". This is the case when they study inequality or, when focusing the world of workplace and organizations, psychosocial qualifies interrelations of individual-group-institutions or individual-society.

There has been increasing consideration for the symbolic and cultural levels as being more expressive of the psychosocial dimension in interaction with other "aspects" or "factors" of social organization and within the subject/individual/person. A growing number of articles define as psychosocial the subject/individual/person's "ways of seeing the world", the production of "discourses" and "meanings" of social, interpersonal, and institutional interactions. Very few, though, further define technical approaches or practices derived from these studies. The term "subject" (sujeito) is often used in this literature, mostly as a synonym for the individual or person, and it is rarely used with clearly defined theoretical significance.

In models that address the psychosocial dimension as an expression of the association of "factors", the term individual is preferred. To recognize cultural diversity and a cultural domain, different variables are used to define individual differences related to "perceptions", "beliefs", "attitudes", “opinions", "knowledge", "norms" and "identities".

It is interesting to note the repeated use of the term psychosocial in reference to a "psychological mode" (modo psicossocial) to organize care for the mentally ill. Centro de Apoio Psicossocial (CAPS: Center for Psychosocial Support) is the terminology included only in the Brazilian SBD and widespread in SciELO articles. As one of the results of the sanitary reform movement, which conceived the SUS, the use of the term psychosocial care expresses a type of mental health care service organized within the community (not in hospitals). Psychosocial refers to the concept of an "extended clinic" and to the centrality of human rights, particularly to the notions of "autonomy" and "dignity" included in the preamble of the Universal Declaration of Human Rights. The psychosocial mode, as it is defined and applied in care models, seeks more profound ways to practice integralidade (comprehensive care) when caring for persons suffering from mental illness and their various "needs". These needs are frequently referred to as rights - to extend means of service provision usually reduced to treating the problem defined by a nosology or by pathological taxonomy. Even in this segment of the literature, particular practices carried out based on a "psychosocial mode" are described very little, and the term often appears to highlight that it "does not all depend on the person" and in opposition to a generic "biomedical model".

It was also interesting to compare these categories with those observed in the international literature. Some years ago, we asked the scientific director of Applied Psychology of the APA the meaning of "psychosocial care" (atenção psicossocial). Recognizing the polysemy of the expression and the lack of a precise definition she offered an explanation taken from the literature in the field of social services, with the intention of presenting "a context for the term":

The term psychosocial describes a constellation of social, emotional and mental health needs, and the care offered to meet them. A broader and related concept is quality of life, from the perspective of the person, including his experience in home and not just in health care. Psychosocial care is multifaceted, now that beyond social workers, other health professionals can contribute to meet psychosocial needs and improve quality of life, which also depend on processes and the general environment in the home of the person. (S. R. Johnson, personal communication, March 21, 2007) $)^{12}$

12 Stephanie R. Johnson PhD. Director of Applied Psychological Science. Science Directorate Amer- 
Our critical review of the international literature $^{13}$ found that, in the decade from 2000 to 2009 , the term "psychosocial" was used to mean: (a) attention to emotional problems or mental suffering that limits the social functioning of patients; (b) the need to organize or support people to cope with the problems of everyday life with a social origin - such as lack of money, housing, hygiene, and access to necessary resources for health care, among others; (c) palliative care to maintain the quality of life for the terminally ill.

Although rarely found in the international literature, as in Brazilian literature we commonly found the notion of psychosocial care associated with (d) assistance that includes the community as partly responsible for organizing the care of patients or of persons with disabilities. In the non-Brazilian literature, texts based on this perspective almost always discussed initiatives taken, developed, and implemented in developing countries, in impoverished communities, or among stigmatized groups (like homosexuals). The focus is often on African countries and those most affected by AIDS where, in the absence of organized health care and medical treatment, the community steps in to help the sick and disabled with palliative care.

In the fields of medicine, nursing, and health psychology, "psychosocial factors" is a category commonly designed for statistical analysis based on associations made among answers to close-ended questionnaires. Parting from quantifiable questions and answers, constructs such as the "life conditions" and the context are transformed into variables that are "socioeconomic" (education, income, religion, ethnicity/race) or "socio-demographic" (such as data on having children or conjugal relations). Most of these studies describe the association of psychosocial factors (low knowledge, for example) as part of peoples' lives who suffer from a "disease" or as

ican Psychological Association. E-mail communication with Eliana Zucchi, March 21, 2007.

13 Search on MEDLINE and SciELO from 20002009 , using the term "psychosocial care" and "atenção psicossocial" carried out with support from Eliana Zuchi and Bruna Robba Lara. an expected psychosocial effect of disease (such as isolation). The way of interpreting these data is often the epidemiology of risk, the mediating knowledge. Some groups of people considered "most at risk" are classified by such analyses as belonging to "risk groups." Psychosocial factors are associated with disease and their relevance in the processes of health-illness, then, validated. Again, significant innovation for care or prevention practices is rarely derived from these studies, however. Innovation is mostly outlined as new "prescriptions" to change patients' attitudes, a practice that remains individualistic: the responsibility of maintaining good behavior and coping with context is placed on the individual.

Studies on sexual health have a more sophisticated theory to interpret the association between various psychosocial factors. These have been influenced largely by sexology, whose ancestors are Freud, Reich, Kinsey and Masters and Johnson (Paiva, 2008).

". . . in fact unemployment can cause erectile problems" (Abdo, Oliveira, Moreira, Abdo, \& Fittipaldi, 2005).

When approached through the social constructivist lens, sexuality is interpreted by considering social interactions ${ }^{14}$, power relations, and human rights - including sexual and reproductive rights. Policy and programmatic action and research agendas are more often derived to understand, intervene, and mitigate sexism, homophobia and gender inequality to the extent

14 John Gagnon is of the social scientists that we consider an ancestor of constructionism and of a dramaturgical approach to the psychosocial, which many authors adopt in this supplement. Interactionist, heir of pragmatism, and influenced by the Chicago School, his use of "career" and "trajectory" helped him define, with Simon (Simon \& Gagnon, 1969) and before Foucault, sex as a social activity like any other and social discourses about sex with a perspective that replaces the notion of impulse. Sexual conduct in physical and symbolic terms, can express other interests (work, politics, and religion), not prioritizing causal explanation. In other words, he inverts Freud's proposition by asserting that sex can mean almost everything in social life and sex had no priority in causal explanation (Gagnon, 2006, p. 406). 
that they are in the literature on women's health and AIDS. Interpretations and practices in this perspective do not aim not for generalizability to all contexts. It was through this perspective that the problems with the notion of "risk groups" was discussed in the context of confronting the Aids epidemic and framed as an additional burden for the lives of those affected. The trivialized notion of risk groups promotes stigma and discrimination of segments of the population identified as at-risk, in addition to encouraging the denial of the problem in people who do not identify with this stigma while not offering appropriate techniques and working practices or procedures in accordance with the principles of SUS (Ayres, Calazans, Saletti, \& França, 2006).

The notion of psychosocial risk, however, is still prevalent in the field of health psychology in hospitals and in epidemiological approaches. This notion prevails even when replacing the term "risk" with "vulnerability" without changing the meaning of the concept, as we will see.

\section{The Psychosocial Dimension in the Organization of Health Practices}

In the field of the organization of health practices, similarly, as we shall see in this section, compound phrases sum up the debate on how the health-disease process is conceived, which produced three paradigmatic movements in the second half of the twentieth century. Compound phrases will also refer to actions that have not been described precisely. As for adolescent health, its definition as "biopsychosocial" aims to broaden the perspective from being exclusively biological or biomedical, calling for multidisciplinary action.

As discussed in Ayres, Paiva and França (2010/2012), the conceptual framework that in the 1950s first postulated overcoming disciplinary boundaries between social intervention in public health and clinical practice, and between treatment and prevention, is known as the model of the "natural history of the disease" (NHD). Leavell and Clark (1958) described periods of a "natural history of disease" (NHD) that require interdisciplinary intervention to address multiple causes considering the three levels of prevention (LP). For this model known as the NHD-LP, primary prevention actions avoid exposure to the disease during the period defined as pre-pathogenic (e.g., through vaccines and by using condoms). In the pathogenic period, when the disease has begun, secondary prevention (through early detection and appropriate clinical intervention) prevents the progression of the disease and its transmission, favoring better individual and collective outcomes; tertiary prevention (through rehabilitation and further treatment) seeks the best quality of life possible in situations of chronic illness and, eventually, developments. In this model and interdisciplinary effort, the epidemiology of risk emerged as one of the main ways to articulate knowledge.

The second movement established the "New Health Promotion" (NHP), following several international conferences in the 1970 s, that reinforced the centrality of prevention practices and primary care, questioning the centrality of the hospital as the focus of political and programmatic action in health. Social sciences applied to health and the recognition of social determinants of health demarcated this movement that conceives the individual and collective health based on principles of the right to health, legalized in the Constitution of 1988 in Brazil. The NHP articulates, at the same time, a comprehensive ("integral") conception of health (physical, mental, social and spiritual), the inter-sectorial action, and involvement in the transformation of social situations as well as in multi-strategic actions that promote equity and sustainability in health initiatives, and the participation of health service clients. ${ }^{15}$ All these became principles of the Brazilian SUS, which the Brazilian response to AIDS sought to implement.

With the NHP, the maneuver of social variables was introduced. The social psychology that is part of this movement identified socio-psychological aspects and factors in the chain of multiple causes responsible for the disease. Through this pursuit of "integralidade" (comprehensiveness), many practices in health psychology were

15 As a result of Sanitary Reform. 
established in Brazil, and psychologists who dialogued with medical clinics and interacted with practices defined by the "biopsychosocial perspective" produced new technical modalities and procedures. F. M. Santos and Vilela (2009) described these as "thought collectives" and identified some of the most structured in general hospitals: Health Psychology, Medical Psychology, Hospital Psychology and Mental Health, which, in health care, are usually based on psychosomatic foundations, psychoanalytic theories, and existential psychology.

Many authors in these traditions have theorized living with AIDS, or interpreted the relationship between lifestyles and the HIV prevention according to socio-psychological models as applied to health. ${ }^{16}$ In the responses to AIDS, these psychologies structured the practice of providing "mental health" services that were specialized for people living with HIV. As discussed in Paiva (2012b), before the production of medical treatments targeting HIV, the international literature on services for the ill was mostly the research on stress and coping, which investigated statistically significant associations between the experiences of everyday life and ways to cope with disease. Later, and especially in thinking about prevention, sociopsychological literature introduced analyses based on social variables (ethnicity, education, place of residence, gender, sexual identity and religion, most prominently). Two theoreticalmethodological fields have mediated these socio-psychological practices within the NHP: traditional epidemiology and behavioral and socio-cognitive psychology.

Other psychosocial approaches dedicated to finding instruments to practice and foster care beyond so-called "mental health" had more difficulty in establishing themselves as valid in the field. Alternatives were developed more easily in the field of prevention and basic health care, where practices were less centered on the tradi-

16 In this last case we refer to Bandura, Proshaska, Lazarus and Folkman, among other well-known authors (Tunala, 2012), who continue to be cited in the international "health psychology" literature. tional "collectives thoughts" and had more incentives for interdisciplinary work. In the case of AIDS, other professionals (nurses, social workers, nutritionists, educators, clinicians, and paramedics) also focused their work on psychosocial factors for post-test counseling, adherence to condoms use and treatment, and various other psycho-educational activities developed in primary care and specialized services.

An alternative reference that was instrumental and more well-defined emerged strongly with the development of a third paradigm for thinking about the health-illness process: the framework of vulnerability and human rights (V\&HR), systematized and internationally validated precisely in the responses to AIDS in the 1990s (Gruskin \& Tarantola, 2008a, 2008b, 2012; Mann \& Tarantola, 1996; Mann, Tarantola, \& Netter, 1992). The V\&HR framework significantly expanded bio-psychological and socio-psychological perspectives, built-in in the New Health Promotion, by incorporating the social determinants of health and then conceiving the vulnerability, both individual and societal, as inextricably tied to a programmatic dimension as Figure 1 illustrate - which bring about the focus on human rights (Gruskin \& Tarantola, 2012; Mann, Gruskin, Grodin, \& Annas, 1999).

In Brazil, the human rights psychosocial perspective was expanded: individual, social and programmatic levels are demarcated as inter-subjective spheres, as dynamic takes place in everyday life, relating to citizenship and the person conceived as a holder of rights (Ayres, Paiva, \& França, 2010/2012; Paiva, 2007, 2012a). This framework produced a constructionist approach to social psychology in health that substituted the notion of the individual as a set of bio-sociopsychological factors as in the original work of Mann and his colleagues. This notion of the individual level has been regarded as of the person in context, conceived as a subject of health and an agent and holder of the right to health (Paiva, 1996, 2002, 2008, 2012a, 2012b). Recognizing that the introduction of social variables in health psychology was crucial progress to the interdisciplinary dialogue, the psychosocial dimension is not centered solely on the "individual," a unit 
of study that the tradition of the social psychology that conceives it as a construct that results from socio-cognitive-behavioral factors. The unit of analysis chosen is the scene of inter-sub- jective interaction (in service provision, daily social life, and in personal trajectories). All levels of vulnerability are mutually inter-related as the figure indicates.

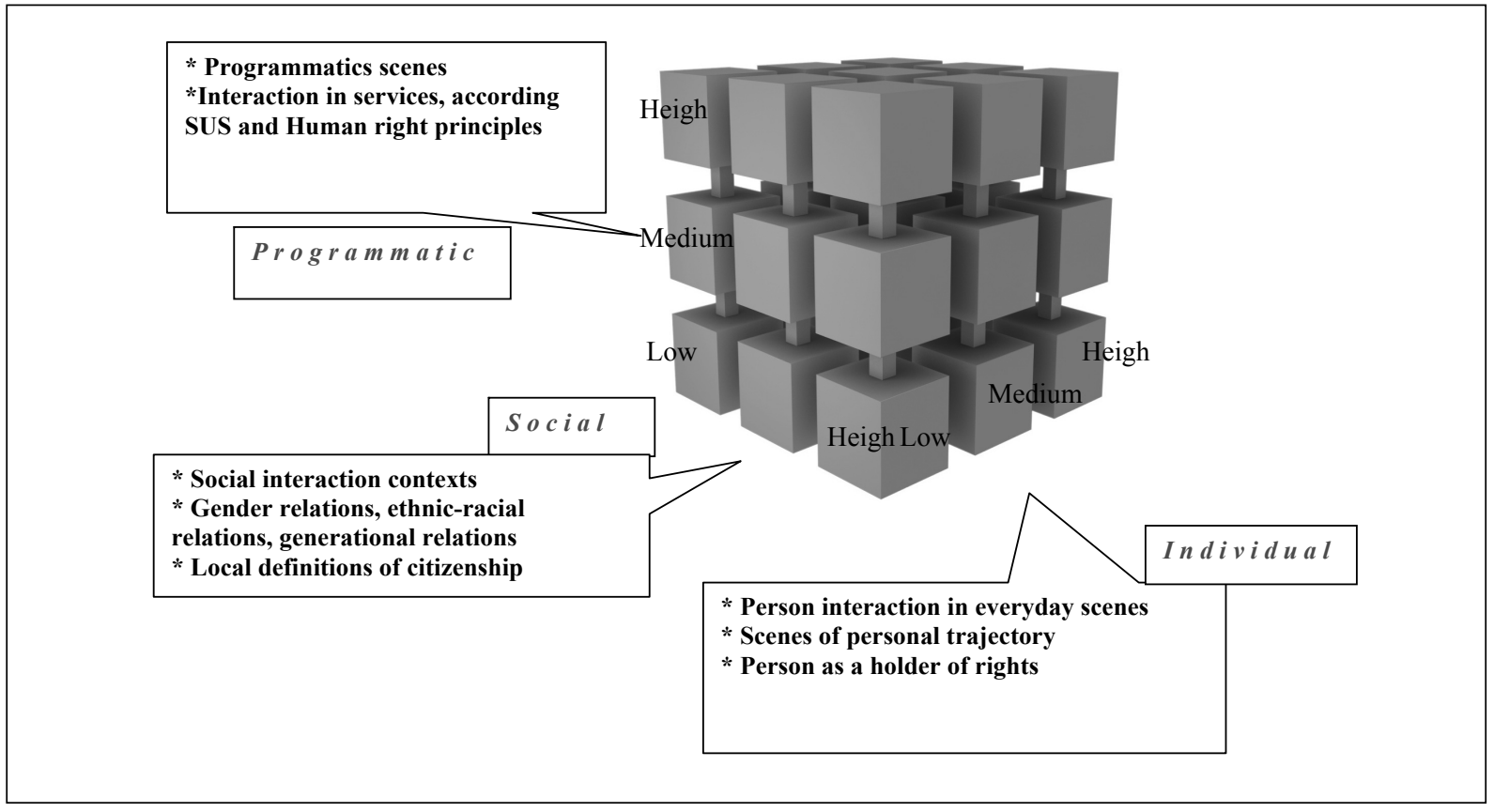

Figura 1 - Inextricability of social, programmatic and individual vulnerability conceived as inter-subjectivity.

The first innovation to be highlighted in this third movement (V\&HR), in contrast to the NHP, is the substantial expansion of the political-programmatic sphere, a social and intersubjective determinant of health, conceived as a mediator of social and individual vulnerability. In sum, vulnerability to the disease of people who belong to the most vulnerable segments of society (e.g., the poor) have diminished or increases due to the presence or absence of health programs (e.g., the availability of vaccines, the existence of basic sanitation, actions to prevent HIV, and access to care and treatment). This approach explains some elements of success in Brazil in reducing the spread of AIDS, even in the 1990s and before reducing poverty, sexism, homophobia and the stigma associated with the disease, or solving problems with drug abuse and universal access to comprehensive health care. AIDS programs developed innovative initiatives that addressed these determinants technically and programmatically, and the results were surprising.
This programmatic mediation, emblematically, shows that the negligence or violation of human rights leads to higher probability of disease. On the other hand, the greater the effort to promote and protect rights - such as to comprehensive health care, to sexual and reproductive rights, counter-discrimination efforts, food security, stable housing, decent work, among others - the higher the likelihood of survival and lower the chance of infection. A principle, in this context, is that every society must protect and promote the rights to health and that their governments (national and local) can be considered responsible in case of negligence or the violation of rights (Gruskin \& Tarantola, 2008a, 2008b, 2012). Health professionals in the SUS and activists have used this principle to meet the demands of social movements, noteworthy in the production of the Brazilian response to AIDS. The goal is to overcome individualization and not blame the victim or the person responsible for his/her carelessness by considering contextual factors associated with his/her illness. 
Programs and practices based on an analysis of vulnerability to disease necessarily depend on the interactive action of the various streams of knowledge (from various clinical areas, epidemiology, the humanities and the social sciences), and practice from the human rights perspective (from management of services to care provision). In other words, they depend on nondiscrimination by the system, on ensuring universal access to health services and their acceptability and quality, and on participation of clients.

The original framework for the so-called individual dimension of vulnerability was, thus, greatly expanded in Brazil. We have set a social psychology different from the original work of Mann and colleagues, although most North American and European literatures and, as you might expect ${ }^{17}$, the United Nations still disseminates the perspective of individual vulnerability (as in Mann et al., 1992, 1997). The Latin American traditions in pedagogy of the oppressed, in psychotherapy and in the theater of the oppressed (Boal, 1975; Freire, 1968/1973; Moffat, 1987; Oliveira \& Araujo, 2012), inspired a psychology devoted to social and community-based action, which some call the "psychosocial intervention" (psycho before social). Noticeable that Psychosocial intervention is a search term in the SBD system and not by the APA, as mentioned above. With implications for the construction of a post-colonial and post-dictatorship citizenship, this same tradition produced "the psychosocial mode", which was introduced in the SUS.

The theoretical-practical movement dedicated to developing a psychosocial approach in health in the framework of V\&HR arose in this context (Paiva, 2012b). The aim in this framework, as in other constructionisms, is to build an alternative to the notion of individual framed as "objects" and change the focus and methods of interventions that aim to model behaviors and educate through "banking pedagogy", as Paulo Freire would define, a non-dialogical and depoliticized pedagogy, or simple moralistic preach-

17 Our domestic production in Latin America cannot be completely detached, especially because we do not write (and hence think) in English. ing (Paiva, 1996, 2002, 2007, 2012a). The Brazilian approach to V\&HR prefer the term person used in the context and language of rights, as well as in definitions of the "subject" as found in the diverse field of constructionism in Psychology (Cañón, 2008). "Subject" here is used as in grammar: an agent who is doing or being something.

In this constructionist psychosocial approach in the context of Human Rights and Vulnerability ${ }^{18}$, the subject is defined (a) as a $s u b$ ject of discourse, which each person encounters is in his/her process of socialization, a process that does not fundamentally dominate him/her. Each person, as anthropology and social health psychology indicate for decades, reinterprets discourses in various contexts of daily life. As "sexual subjects", for example, men and women redefine the diverse discourses surrounding sex (e.g., prevention discourses, religion discourses, and the media) to carry out their sexuality on each occasion and scene (Paiva, 1996, 2007). As "religious subjects", they interpret religious dogmas and discourses adapting them to their personal practice of religiosity (García, MuñozLaboy, Almeida, \& Parker, 2009; Silva, Santos, Licciardi, \& Paiva, 2008). As (b) subject of rights in solidarity with others, they can promote, expand and specify of new rights. Services should see clients in the intimacy of its practices and techniques drawing on this psychosocial approach: patients as subjects-agents in each encounter to receive care, as subjects-agents of learning in solidarity with others, as agents of psychosocial emancipation from oppression and vulnerability to disease (Paiva, 2002, 2008, 2012a; Seffner, Paiva, \& Pupo, 2012).

The Latin American scholastic production on this framework of the social psychology of health, therefore, bears the same kind of critical

18 When we understand and interpret data from various knowledge sources about the vulnerability of a person or social group to a health problem I often say that we are in the framework of the V\&DH. When we are designing and planning practice, the principles of human rights approaches are highlighted and so I invert the acronym to $\mathrm{DH} \& \mathrm{~V}$. 
reflection expressed by Frosh (2013), who also discusses the limits of the so-called individualizing socio-psychological theories. Frosh stresses that individualizing social psychology will study cognitions and behaviors in social contexts operating with the notion of the individual as a fact, not as a social construction, upholding the intellectual division of labor that separates different disciplines that study society (reminiscent of social before the hyphen/space in social psychology) from those studying the individual ( $p s y$ chology after the hyphen-space). Frosh among others, values the intersection of the two realms. Another challenge, in his view, is overcoming the idea that there is something "objective," the individual, which can be studied from a "neutral" perspective without responding to the context and the ideas that he/she inhabits. The author, as in Butler's (1997) formulation, supports the idea that the person can be a "subject to the workings of society" and a subject in the sense of the power to act in the world, to conceive and investigate a subject that is both social and psychological as well as to overcoming repression, owning agency and inner life.

In Brazil, since the 1990s, this same criticism informed the production of the various aspects of social constructivist psychology, as in the study of health (Paiva 1996, 2005, 2008, 2012b; Spink, 2013). As you might expect, many authors involved in the response to AIDS at some point in their careers came together with this perspective. ${ }^{19}$ We all recognize the central-

19 The Brazil organized for 18 years the largest gathering that discusses gender exclusively ("Making Gender") which brings together thousands of Brazilian researchers, literally. Latin America is a co-producer of the great epistemological shift produced by constructionist studies of gender and sexuality constructionist which is a key inspiration of that strand of psychology for over two decades. As Terezita de Barbieri synthesized, the production gender category for analysis is "an epistemological rupture, perhaps the most important in the social sciences in the last 20 years, because it recognizes a dimension of social inequality until then addressed, subsumed the economic sphere, in theories of class and social stratification" (Barbieri, 1991). ity of the field of gender and sexuality studies, which extended its legitimacy precisely in the response to AIDS and as was necessary to the organization of integral women's health care.

Placing our constructionist analysis within the framework of human rights and vulnerability, it seems significant that the social comes before psychological in models of health psychology or socio-psychological epidemiology. As mediated knowledge to inform practices, both theorize the associations among factors obtained in large samples, from aggregated populationlevel data about tendencies and likelihoods that make sense only for studies on macro-social levels. In the absence of other expertizes and input from other areas of knowledge (social science, education), practices and preventive measures follow the same trends, unduly colonizing prevention as if the dynamics in people's daily lives mirrored statistical associations. In doing this, these approaches did not provide the technical resources to innovate the practice, especially in contexts of high inequality. External analysis of risk unduly colonizes other fields of knowledge, such as those dedicated to care provision and prevention, with recipes of "suitable lifestyles" prescribed to "generic individuals", to their bio-psychological behaviors and typical-persons, which do not exist in the real world. An example of this colonization is ineffective preaching and insistence on the universal use of condoms, which more than 20 years later has shown its limitations. The AIDS social movement in Brazil has insisted that in the 4th decade of the epidemic we should finally focus on prevention taking into account gender relations (women do not use condoms that are available, depending on the conversation) and that each person has the right to use all available resources in the context of sexual interactions, including biomedical prevention. ${ }^{20}$

As recently synthesized by Kippax, Stephenson, Parker and Aggleton (2013), the conceptions of the individual level used in the fields of epidemiology to study risk and social psychology, and by a World Health Organiza-

20 See http://oquenostiraosono.tumblr.com/home 
tion $^{21}$ version the V\&HR framework, disregard: (a) that people's actions are not just products of their characteristics or their rational decisions, but that they involve systems of meanings and understanding; (b) that, when the behavior of the person is reduced to a certain behavior (e.g., sex without condoms), we overlook the diversity of meanings given to sexual practices over time by the same person in different places, roles and occasions (e.g., as a spouse or lover, for love or in the context of being abused); (c) that cultural normativity and social practices constantly produce the individual and their practices.

Kippax and colleagues (2013) replace the focus on the individual with community-based prevention, centering on collective action and interaction between groups and networks of people. They argue that social and behavioral changes that have been articulated in the community transformed the course of the AIDS epidemic. The centrality of community mobilization for health promotion is highlighted in the re-invention of the condom use: originally an artifact of contraception, it has become the norm among homosexual men who in the 1980s organized themselves in a social movement in resistance to the epidemic. They also argue that the mobilization based on solidarity and community-based care produced universal access to antiretroviral treatment in the Brazilian response to AIDS, as discussed in several articles in this supplement.

On the other hand, the challenges identified by Frosh, by Kippax and other constructionists seem almost insurmountable for anyone working in the health fields where, due to an ambition for objectivity that does not consider socio-cultural norms and to an undeniable practical effect of the surgical and clinical intervention on the individual's body. Considering the process of treatment for a person living with HIV or AIDS, for example. Medical protocols depend on a set of theoretical hypotheses tested through techniques and practices based on rigorous handling of substances, products, manipulating bodies extracted from their social contexts in testing and treating.

21 Expressed in the document (Joint United Nations Program on HIV/AIDS [UNAIDS], 2011).
Here or in any other continent, the results have efficacy! Antiretrovirals control HIV infection anywhere in the world. Alternatively, multidisciplinary and multi-sectorial spaces depend on surpassing this biomedical construct of individual to include techno-scientific approaches that recognize that the remedies are effective when access to treatment and adherence is guaranteed and sustained, through working processes that need psychosocial approaches, inextricably linked to sociocultural contexts, as this special issue will show.

This same discussion took place in the field of sexuality, and it also seemed insurmountable at the beginning of the AIDS epidemic, when the global literature and the psychological theories and practices exported to several other academic disciplines (to education and health, e.g.) expressed the hegemonic sexological tradition. Sexology conceives sex as bio-psychological with equal and universal psychosexual development and dynamics, regardless of context. This approach is still engaged in trying to reveal essential truths about sex, and what is psychosexually normal based in clinical investigation or population surveys. Its results derive the clinical practice to treat sexual disorders and educational interventions to model safe behavior. This perspective clearly had poor efficacy for the prevention of HIV through sexual transmission in contexts of social inequality. The response to AIDS highlighted the limitations of this sexological conception of sex and of the techniques used to derive interventions to ensure "normal psychosexual development" or "healthier behavior" as seen in programs for adolescent, a theme that was developed in other texts (Paiva, 2008, 2012b; Paiva, Ayres, \& França, 2004).

The recognition of the limits of essentialism in the responses to AIDS allowed for the growth of alternative viewpoints. Especially in the southern hemisphere or northern hemisphere areas where it was clear that a synergism of plagues (Parker \& de Camargo, 2000) produces social inequality based on relations of domination based on class, sexism, racism and the naturalization of genocide, evidenced by the explosion in the number of AIDS cases among those 
who are most marginalized along these lines. The uncontrolled epidemic demanded a critical reflection that reformulated protocols for practice, and allowed for the technical renovation (defined as a practical and operative knowledge that is characteristically normative, prescriptive and methodological) and theoretical renovation (of the analytical nature of knowledge and understanding), both developed within the ethicalpolitical human rights framework.

In other words, when there is a synergy of inequalities, stigma, and increased vulnerability to disease, a hyphen or a space (between areas of study) does not make a significant difference! Those who are involved in health promotion need to conceptualize arrows showing interaction and integration, a synergy of knowledge, and interventions along different personal, institutional, structural and political dimensions. The emergence of the AIDS epidemic, everywhere, intensified the need to act in synchrony, dynamically and simultaneously along all dimensions that affect the health-disease process. In this regard, interdisciplinary dialogue is critical while the integrated spaces for action rebuild practices arising from this dialogue for the benefit of groups perversely included in social life through discrimination (Ayres, Paiva, \& Buchalla, 2012).

Therefore, a second innovation of the V\&HR Brazilian framework, which also distinguishes it from other constructionist psychosocial approaches, is its ambition to produce fertile encounters among diverse fields of knowledge. The increasing inclusion of the hermeneutics in the Brazilian version of the V\&HR framework makes it different. The philosophical hermeneutics as used in the work of Gadamer (1997), and not only in the methodological sense, offered a perspective of the relationship self-other, not only in its cognitive aspects, but also in its ethical, moral, political and aesthetic aspects (Ayres, 2007, 2008). In dealing with vulnerability by addressing individual and social dimensions, as well as its programmatic level, these hermeneutics avoid an objectivism that promotes reduction of the social into categorical lifestyles, the dichotomy between the individual and the collective, between the biological and the social world. This hermeneutical approach may also prevent a purely instrumental meaning of structural aspects and a politicization kept out (external) of techno-scientific features. Sociostructural aspects are acknowledged as necessary and inextricably embedded in practices (defined as knowledge based on interpersonal relations, inter-subjectivity, and that is both responsive and tailored). This hermeneutic support politicized theory and technique in the details of its protocols. ${ }^{22}$

This hermeneutics produced the idea of Care (with a capital letter) in the using the framework of vulnerability (Ayres, 2004a, 2004b) and valued the importance of care adopted in various fields of knowledge and practice in health (Pinheiro \& Lopes, 2010; Pinheiro \& Mattos, 2006). Motivated by different routes and experiences, the focus of the V\&HR movement in this philosophical perspective by several Brazilian authors in the fields of medicine, nutrition, women's health, and nursing allowed for the production of a psychosocial theory-technique that calls our attention to the importance of psychology and to the relevance of this perspective.

Objectivism, dichotomies, and the structural understood as a barrier, as well as politics conceived as an external factor, persist in the discourses and proposals of the NHP and, inappropriately, in versions of vulnerability analysis criticized by Kippax and colleagues (2013). In Brazil, these versions simply substitute the word "risk" for "vulnerability" without changing meanings. In Brazil, the pedagogy of Paulo Freire had already exceeded this externalization in the field of education, with his pedagogy anti-colonization that has inspired health promotion worldwide. The inclusion of hermeneutics in Brazilian V\&HR strengthened the option for the use of multicultural and emancipatory approaches to addressing Human Rights, as in Boaventura Souza Santos (2003). Santos "diatopical hermeneutics" operationalize human rights approaches characterized by an antico-

22 On these definitions of theory, technique and practice see Pupo (2012). 
lonial preoccupation, similar to the position of Freire (Paiva, 2012a).

This second development, the hermeneutic perspective, emphasizes the centrality of intersubjectivity for thinking about health issues on individual, social and programmatic levels (as shown in Figure 1) and for critical reflection on individualism. Due to the strong sense of dialogue in hermeneutic perspective, as for Gadamer, is the "fusion of horizons" (Ayres, 2007), critical thinking is carried out with the direct involvement of service clients in places where they receive care as well as in institutional and political spaces. Psychosocial approaches are involved in the production of practices in care provision, prevention and education, as well as in health programming and management. It is possible to recover the inter-subjective dimension while planning for in structural interventions: instead of just blaming the macro-social imprints of inequality, it leads us to understand the concrete aspects of relations of gender, race, class, and generations in everyday life. It fosters the permanent assessment of inequalities that are reproduced and sustained through health practices, in how they are carried out in different territories, in the experiences of every person.

Finally, the psychosocial perspective of health used throughout this Brazilian framework of V\&HR does not ignore the centrality of the person, understood in relation to others and as the subject (sujeito), as a holder of human rights. As a "sujeito" in relation, "inter-subject", each person can experience illness and protect her/himself from it, which involves their physical constitution and personal way to living daily as part of a community. As a subject holder of rights, the person can claim them, or as agent of the state or community in solidarity with others, the person can promote and protect the rights of others who he/she sees as co-citizens. Communities do not exist in abstract notions defined by norms. Besides being embodied in people who are institutional actors to legitimize norms, values and the history of a community on a daily basis, persons have to reproduce them in the socialization of new generations. Or rather, communities depend on people for action and trans- formation, some persons can be inspiring and co-organize social movements that can fail or decline without them. ${ }^{23}$

This perspective and its approaches for health using the framework of human rights and vulnerability, therefore, are psychosocial and not socio-psychological.

Through this interpretation, vulnerability to disease is the vulnerability of a person (a woman) - not a risk group (prostitutes) or community (a territory or a group that shares solidarity in an identity) - in any particular social situation (lived by the person as a dynamic scene within a sociocultural scenario), where their rights to dignity, autonomy and freedom are protected or violated and neglected. Social and individual vulnerability to health problems will be worse or better depending on the absence or presence of programs (for prevention, support, or for health care). Most women living with HIV in Brazil who had, on average, only one or two partners in their lives or are sex workers excluded of basic rights and programs- exemplify this perspective!

\section{The Process of Innovating Practice Should aim to Renew Theory}

The contributions of the social sciences, history and philosophy have been instrumental in the design of new practices and theoretical innovations produced in the context of the Brazilian response to AIDS. In the case of the psychology of health, its most politicized social psychology has inspired even the clinical knowledge, if it focus on the inter-subjective. This approach has generated multi-professional collectives that take into account the health of the individual and

23 The notion of the "embodiment" is used in the same sense in the notion of "embodied health movements" which describe health movements in the United States (Brown et al., 2004). The authors argue that these movements present the biological body in social movements in the accounts of their experiences of suffering and neglect, especially their emotional experience and not just the cognitive aspects; questioning hegemonic medicine and science, including activists in collaboration with scientists and professionals to access to health treatment, prevention, research and funding. 
the collective health within the SUS. The path to validate its practical efficacy and expertise, to apply knowledge and principles to each specific question and challenge, to translate it into concrete actions in daily work affecting care for people living with AIDS or socially vulnerable populations, has been long. As in this and other articles in this supplement discusses, the use of the vulnerability framework clearly taught us that there is not a Natural History of Disease, but a Social History of Disease. The disease has social and historical aspects, and the history of a disease as well as its response is told through social scenes (Ayres, Paiva, \& França, 2010/2012).

In the case of AIDS, the Brazilian response needed to be articulated through health practices of a universal system that did not exist when the epidemic began. Parallel to the emergence of the epidemic, to take into account the commitment of universality, equity and integrity, the Program for Integral Attention to Women's Health (PAISM) was already an innovation, surpassing the script of "maternal and child health" by using other terms: "women" and "integral". The feminist-Marxist and constructionist perspective found in the social sciences, education, and in the field of sexual and reproductive health that today mark the movement of humanization in health practices and the Aids response in Brazil dates back to the 1980s. This movement was, then, nuanced by the Latin American production of community social psychology, its focus on the oppressed, and the psychosocial intervention mode in dialogue with the anti-psychiatry movement in Brazil, institutionalized in the Psychiatric Reform and Anti-Sanatorium Movement, which produced the "psychosocial mode" in mental health care.

Only recently has this effort for critical reflection and systematization of practices, required by the organization of the SUS and, more recently, of a Unified Social Assistance System (SUAS), begun to result in written texts that reflect an important theoretical innovation. This production is especially noticeable in the second decade of the 21 st century. It takes courage to transform thinking and collective practices thought theoretical contributions to support the disciplinary training of Brazilian psychologists in future generations.

We hope that new generations of psychologist do not have to reinvent the wheel each time, grappling with dogmatic schools of thought based on this or that author from another century, or drawn from socio-psychological notions from other social contexts. We hope that this supplement will help stimulate others from different fields and thematic interests, with the same spirit of theoretical, technical, and practical innovation!

\section{References}

Abdo, C. H., Oliveira, W. M. de, Jr., Moreira, E., Jr., Abdo, J. A., \& Fittipaldi, J. A. S. (2005). The impact of psychosocial factors on the risk of erectile dysfunction and inhibition of sexual desire in a sample of the Brazilian population. São Paulo Medical Journal, 123(1). Retrieved June 17, 2009, from http://www.scielo. br/scielo.php?script $=$ sci_arttext\&pid $=$ S1516$-31802005000100003 \& \operatorname{lng}=\mathrm{en} \& \mathrm{nrm}=$ iso

Ayres, J. R. (2004a). Cuidado e reconstrução das práticas de saúde. Interface: Comunicação, Saúde e Educação, 8(14), 73-92.

Ayres, J. R. (2004b). O cuidado, os modos de ser (do) humano e as práticas de saúde. Saúde e Sociedade, 13(3), 16-29.

Ayres, J. R. (2007). Uma concepção hermenêutica de saúde. Physis, 17, 43-62.

Ayres, J. R. (2008). Para comprender el sentido práctico de las acciones de salud: contribuciones de la herméutica filosófica. Salud Colectiva, 4, 159172.

Ayres, J. R., Calazans, G., Saletti, H., Filho, \& França, I., Jr. (2006). Risco, vulnerabilidade e práticas de prevenção e promoção de saúde. In G. W. S. Campos, M. C. S. Minayo, M. Akerman, M. Drumond Jr., \& Y. M. Carvalho (Orgs.), Tratado de Saúde Coletiva (pp. 375-417). São Paulo, SP: Hucitec.

Ayres, J. R., Paiva, V., \& Buchalla, C. M. (2012). Direitos Humanos e Vulnerabilidade na Prevenção e Promoção da Saúde: Uma introdução. In V. Paiva, J. R. Ayres, \& C. M. Buchalla (Orgs.), Coletânea: Vulnerabilidade e Direitos Humanos. Prevenção e promoção da saúde: Vol. 1. Da doença à cidadania (pp. 9-22). Curitiba, PR: Juruá. 
Ayres, J. R., Paiva, V., \& Franca, I., Jr. (2012). Conceitos e práticas de prevenção: Da História Natural da Doença ao Quadro da Vulnerabilidade e Direitos Humanos. In V. Paiva, J. R. Ayres, \& C. M. Buchalla (Orgs.), Coletânea: Vulnerabilidade e Direitos Humanos. Prevenção e promoção da saúde: Vol. 1. Da doença à cidadania (pp. 71-94). Curitiba, PR: Juruá. (Reproduzido a partir de Routledge Handbook of Global Public Health, Vol. 1, pp. 98-107, de R. Parker \& M. Sommer, Eds., 2010, London: Routledge)

Barbieri, T. (1991). Sobre la categoría género. Una introducción teórico-metodológica. In S. Azerêdo \& V. Stolcke (Coords.), Direitos reprodutivos (pp. 25-45). São Paulo, SP: Fundação Carlos Chagas.

Berkman, A., Garcia, J., Muñoz-Laboy, M., Paiva, V., \& Parker, R. (2005). A critical analysis of the Brazilian response to HIV/AIDS: Lessons learned for controlling and mitigating the epidemic in developing countries. American Journal of Public Health, 95(7).

Boal, A. (1975). Teatro do oprimido e outras poéticas politicas [Theatre of the Oppressed]. Rio de Janeiro, RJ: Civilização Brasileira.

Brah, A. (2006, jan./jun.). Diferença, diversidade, diferenciação. Cadernos Pagu, (26), 329-376.

Brown, P., Zavestoski, S., McCormick, S., Mayer, B., Morello-Frosch, R., \& Gasior Altman, R. G. (2004, January). Embodied health movements: New approaches to social movements in health Sociology. Health \& Illness, 26(1), 50-80.

Butler, J. (1997). The Psychic life of Power: Theories in subjection. Stanford, CA: Stanford University Press.

Cañón, O. E. (2008). Las huellas del sujeto en narrativas de autores construccionistas [Subject's tracks in the narratives of constructionista authors]. Revista Diversitas - Perspectivas em Psicologia, 4(2), 245-257.

Freire, P. (1973). Pedagogia do Oprimido. Rio de Janeiro, RJ: Paz e Terra. (Original publicado em 1968)

Frosh, S. (2013). Psychosocial Theory. In T. Teo (Ed.), Encyclopedia of Critical Psychology. New York: Springer.

Gadamer, H. G. (1997). Verdade e método: Traços fundamentais de uma hermenêutica filosófica. Petrópolis, RJ: Vozes.
Gagnon, J. (2006). Uma interpretação do desejo: Ensaios sobre o estudo da sexualidade. Rio de Janeiro, RJ: Garamond.

García, J., Muñoz-Laboy, M., Almeida, V., \& Parker, R. (2009). Local impacts of religious discourses on rights to express same-sex sexual desires in peri-urban Rio de Janeiro. Sexuality Research \& Social Policy, 6(3), 44-60.

Greco, D. B., \& Simão, M. (2007, July 21). Brazilian policy of universal access to AIDS treatment: Sustainability challenges and perspectives. AIDS (Suppl. 4), 37-45.

Gruskin, S., \& Tarantola, D. (2008a). Health and Human Rights: Overview. In K. Heggenhougen \& S. R. Quah (Eds.), International encyclopedia of public health (Vol. 3. pp. 137-146). San Diego, CA: Academic Press.

Gruskin, S., \& Tarantola, D. (2008b). Universal Access to HIV prevention, treatment and care: Assessing the inclusion of human rights in international and national strategic plans. AIDS, 22(Suppl. 2), 123-32.

Gruskin, S., \& Tarantola, D. (2012). Um panorama sobre saúde e direitos humanos. In V. Paiva, J. R. Ayres, \& C. M. Buchalla (Orgs.), Coletânea: Vulnerabilidade e Direitos Humanos. Prevenção e promoção da saúde: Vol. 1. Da doença à cidadania (pp. 23-41). Curitiba, PR: Juruá.

Hogget, P. (2008). What's in a Hyphen? Reconstructing psychosocial studies. London: Palgrave.

Joint United Nations Program on HIV/AIDS. (2011, October). UNAIDS Terminology Guidelines. Retrieved October, 2011, from http://www.unaids. org/en/media/unaids/contentassets/documents/ unaidspublication/2011/JC2118_terminology-guidelines_en.pdf

Kalichman, A., \& Diniz, S. (2009). AIDS treatment in Brazil: What kind of evidence do we need? The Lancet, 374(969), 1066.

Kerrigan, D., Wirtz, A., Baral, S., Decker, M., Murray, L., Poteat, T., \& Beyrer, C. (2013). The Global HIV Epidemics among Sex Workers. Washington, DC: World Bank.

Kippax, S., Stephenson, N., Parker, R. G., \& Aggleton, P. (2013, June 13). Between Individual Agency and Structure in HIV Prevention: Understanding the Middle Ground of Social Practice. American Journal of Public Health, 103(8), 1367-1375. 
Leavell, H. R., \& Clark, E. G. (1958). Textbook of Preventive Medicine. New York: McGraw-Hill

Malta, M., \& Beyrer, C. (2013). The HIV epidemic and human rights violations in Brazil. Journal of the International AIDS Society, 16, 18817. Retrieved from http://www.jiasociety.org/index. php/jias/article/view/18817

Mann, J., Gruskin, S., Grodin, M., \& Annas, G. (Eds.). (1999). Health and human rights: A reader. New York: Routledge.

Mann, J., \& Tarantola, D. J. (Eds.). (1996). AIDS in the world II. New York: Oxford University Press.

Mann, J., Tarantola, D. J., \& Netter, T. W. (Eds.). (1992). AIDS in the world. Cambridge, MA: Havard Universty Press.

Mann, J., Tarantola, D. J., \& Netter, T. W. (1997). A AIDS no mundo. Rio de Janeiro, RJ: Relume Dumará

Ministério da Saúde. (1993). Normas de atenção à saúde integral de adolescente: Vol. 1. Diretrizes gerais para atendimento de adolescentes. Acompanhamento do crescimento e desenvolvimento. Distúrbios da puberdade. Desenvolvimento psicológico do adolescente. Brasília, DF: Autor.

Ministério da Saúde. (2008). Portaria $n^{\circ} 154$. Cria os Núcleos de Apoio à Saúde da Família/NASF. Brasília, DF: Autor.

Moffat, A. (1987). Psicoterapia do Oprimido. São Paulo, SP: Cortez.

Nunn, A. S., da Fonseca, E. M., Bastos, F. I., \& Gruskin, S. (2009). AIDS treatment in Brazil: Impacts and challenges. Health Affairs, 28(4), 1103-1113.

Oliveira, E. C., \& Araújo, M. F. (2012). Aproximações do Teatro do Oprimido com a Psicologia e o Psicodrama. Psicologia: Ciência e Profissão, $32(2), 340-355$.

Paiva, V. (1996). Sexualidades adolescentes: Escolaridade e gênero, e o sujeito sexual. In R. Parker \& R. Barbosa (Orgs.), Sexualidades Brasileiras (Vol. 1, pp. 213-224). Rio de Janeiro, RJ: Relume-Dumará

Paiva, V. (2002). Sem mágicas soluções: A prevenção e o cuidado em HIV/AIDS e o processo de emancipação psicossocial. Interface: Comunicação, Saúde e Educação, 6(11), 25-38.
Paiva, V. (2005). Analysing sexual experiences through scenes: A framework for the evaluation of sexuality education. Sex Education (London), 5(4), 345-358.

Paiva, V. (2007). Gendered scripts and the sexual scene: Promoting sexual subjects among Brazilian Teenagers. In Culture, Society and Sexuality. A reader ( $2^{\text {nd }}$ ed. $)$. New York: Routledge.

Paiva, V. (2008). A psicologia redescobrirá a sexualidade? Psicologia em Estudo, 13, 641-651.

Paiva, V. (2012a). Cenas da Vida Cotidiana: Metodologia para compreender e reduzir a vulnerabilidade na perspectiva dos Direitos Humanos. In V. Paiva, J. R. Ayres, \& C. M. Buchalla (Orgs.), Coletânea: Vulnerabilidade e Direitos Humanos. Prevenção e promoção da saúde: Vol. 1. Da doença à cidadania (pp. 165-208). Curitiba, PR: Juruá.

Paiva, V. (2012b). A dimensão psicossocial do cuidado. In V. Paiva, G. Calazans, \& A. Segurado (Orgs.), Coletânea: Vulnerabilidade e Direitos Humanos. Prevenção e promoção da saúde: Vol. 2. Entre indivíduos e comunidades (2. ed., pp. 41-72). Curitiba, PR: Juruá.

Paiva, V., Ayres, J. R., \& Franca, I., Jr. (2004, January). Expanding the flexibility of normative patterns in youth sexuality and prevention programs. Sexuality Research \& Social Policy, l(1).

Parker, R., \& de Camargo, K., Jr. (2000). Pobreza e HIV/AIDS: Aspectos antropológicos e sociológicos. Cadernos de Saúde Pública, 16(1), 89-102.

Pinheiro, R., \& Lopes, T. C. (Orgs.). (2010). Ética, técnica e formação: As razões do cuidado como direito à saúde. Rio de Janeiro, RJ: Centro de Estudos e Pesquisa em Saúde Coletiva.

Pinheiro, R., \& Mattos, R. A. (2006). Cuidado: As fronteiras da integralidade. Rio de Janeiro, RJ: Centro de Estudos e Pesquisa em Saúde Coletiva.

Pupo, L. R. (2012). As dimensões teórica, técnica e ético-operacional: Multidimensionalidade da ação preventiva e de cuidado à saúde. In V. Paiva, G. Calazans, \& A. Segurado (Orgs.), Coletânea: Vulnerabilidade e Direitos Humanos. Prevenção e promoção da saúde: Vol. 2. Entre indivíduos e comunidades (2. ed., pp. 41-72). Curitiba, PR: Juruá. 
Rother, E. T. (2007). Revisão sistemática X revisão narrativa. Acta Paulista de Enfermagem, 20(2), 5-6. Recuperado em 26 de setembro, 2013, de http://www.scielo.br/ scielo.php?script $=$ sci_arttext\&pid $=\mathrm{S} 0103$ $-21002007000200001 \& \operatorname{lng}=$ en $\&$ tlng $=$ pt. $10.1590 / \mathrm{S} 0103-21002007000200001$

Santos, B. S. (2003). Reconhecer para libertar: Os caminhos do cosmopolitismo multi-cultural. Rio de Janeiro, RJ: Civilização Brasileira.

Santos, F. M., \& Jacó-Vilela, A. M. (2009, maio/ ago.). O psicólogo no hospital geral: Estilos e coletivos de pensamento. Paidéia (Ribeirão Preto), $19(43), 189-197$.

Scott, J. W. (1995, jul./dez.). Gênero: Uma categoria útil de análise histórica. Educação \& Realidade, 20(2), 71-99. (Revisão de T. T. da Silva a partir de Gender and the Politics of History, de J. W. Scott, 1988, pp. 28-50, New York: Columbia University Press)

Seffner, F., Paiva, V., \& Pupo, L. (2012). Educação em saúde e emancipação: Explorando possibilidades da prevenção no quadro dos direitos humanos In V. Paiva, L. Rivero Pupo, \& F. Seffner (Orgs.), Coletânea: Vulnerabilidade e Direitos Humanos - Prevenção e promoção da saúde: Vol. 3. Pluralidade de vozes e inovação de práticas (pp. 253-268.). Curitiba, PR: Juruá.
Silva, C. G., Santos, A. O., Licciardi, D. C., \& Paiva, V. (2008). Religiosidade, juventude e sexualidade: Entre a autonomia e a rigidez. Psicologia em Estudo, 13(4).

Simon, W., \& Gagnon, J. H. (1969). On psychosocial development. In D. A. Goslin (Ed.), Handbook of Socialization Theory and Research (pp. 733752). Chicago, IL: Rand McNally.

Spink, M. J. (2013). Psicologia Social e Saúde. Práticas, saberes e sentidos. Petrópolis, RJ: Vozes

Tunala, G. L. (2012). Modelos teóricos como subsídios da prática da promoção da saúde em DST/ Aids no quadro da vulnerabilidade e dos direitos humanos. In V. Paiva, G. Calazans, \& A. Segurado (Orgs.), Coletânea: Vulnerabilidade e Direitos Humanos. Prevenção e promoção da saúde: Vol. 2. Entre indivíduos e comunidades (2. ed.). Curitiba, PR: Juruá. 